\title{
Control of Instability of $\mathrm{Si}_{3} \mathrm{~N}_{4}$ during Pressureless Sintering
}

\author{
Shigetaka WADA \\ Toyota CRDL and Toyota Technological Institute, Nagakute, Aichi 480-1192 \\ 常圧焼結における窒化ケイ素不安定性制御 \\ 和田重孝 \\ (株)豊田中央研究所兼豊田工業大学, 480-1192 愛知郡長久手町
}

\begin{abstract}
The instabilities of $\mathrm{Si}_{3} \mathrm{~N}_{4}$ and $\mathrm{Si}_{3} \mathrm{~N}_{4}$ ceramics during sintering are investigated. As a result of the instabilities, $\mathrm{Si}_{3} \mathrm{~N}_{4}$ and $\mathrm{Si}_{3} \mathrm{~N}_{4}$ ceramics lose their mass or decompose. The major mass loss reaction of $\mathrm{Si}_{3} \mathrm{~N}_{4}$ ceramics is shown as follows.

$\mathrm{Si}_{3} \mathrm{~N}_{4}(\mathrm{~s})+3 \mathrm{SiO}_{2}(\mathrm{l})=6 \mathrm{SiO}(\mathrm{g})+2 \mathrm{~N}_{2}(\mathrm{~g})$

Regarding the mass loss, decreasing the sintering temperature by $30 \mathrm{~K}$ corresponds to an increase in $\mathrm{N}_{2}$ pressure in the furnace by one order magnitude. By understanding well the mass loss phenomenon, $\mathrm{Si}_{3} \mathrm{~N}_{4}$ ceramics will be produced commercially in $0.1 \mathrm{MPa} \mathrm{N}_{2}$ gas or air.

[Received May 18, 2001]
\end{abstract}

Key-words : Decomposition, $\mathrm{Si}_{3} \mathrm{~N}_{4}$ ceramics, Sintering, SiO(g), Sagger, Air furnace

1. Introduction

$\mathbf{I}_{\mathrm{s}}$ 1955, Collins and Gerby reported that reaction-sintered $\mathrm{Si}_{3} \mathrm{~N}_{4}$ has excellent mechanical properties. ${ }^{1)}$ In 1961, Deeley consolidated $\mathrm{Si}_{3} \mathrm{~N}_{4}$ ceramics from $\mathrm{Si}_{3} \mathrm{~N}_{4}$ powder using a hot-press method.2) Terwilliger ${ }^{3)}$ and Terwilliger and Lange ${ }^{4)}$ showed the possibility of consolidation of $\mathrm{Si}_{3} \mathrm{~N}_{4}$ ceramics in $0.1 \mathrm{MPa} \mathrm{N} \mathrm{N}_{2}$ gas in 1974 and 1975 , respectively. However, the properties of the ceramics were not safficient for practical applications. In 1976, Mitomo reported the advantage of sintering $\mathrm{Si}_{3} \mathrm{~N}_{4}$ ceramics at high $\mathrm{N}_{2}$ gas pressure. ${ }^{5)}$ However, the mechanical properties were still unsatisfactory.

$\mathrm{Si}_{3} \mathrm{~N}_{4}$ powders with excellent sinterability and sintering additives to reduce sintering temperature were developed in the 1980s. Consequently, $\mathrm{Si}_{3} \mathrm{~N}_{4}$ ceramics can now be sintered at $2000-2100 \mathrm{~K}$.

High mechanical strength at elevated temperatures and large fracture toughness $\left(K_{\mathrm{IC}}\right)$ are the merits of $\mathrm{Si}_{3} \mathrm{~N}_{4}$ ceramics. To improve those properties, sintering at temperatures above $2000 \mathrm{~K}$ is recommended to attain a morphology with a large aspect ratio and a small amount of the grain boundary phase. During sintering at elevated temperature, however, mass loss of $\mathrm{Si}_{3} \mathrm{~N}_{4}$ ceramics occurs. Since an inhomogeneous surface layer or a porous layer is generated as a result of the mass loss, the loss should be decreased as small as possible.

The stability of $\mathrm{Si}_{3} \mathrm{~N}_{4}$ and the $\mathrm{Si}-\mathrm{O}-\mathrm{N}$ system at elevated temperature has been studied thermodynamically. ${ }^{6)-12)}$ Mass loss of $\mathrm{Si}_{3} \mathrm{~N}_{4}$ ceramics during sintering as a result of the instability has been investigated experimentally. ${ }^{13)-21}$ ) Although various reactions involved in the instability and mass loss have been reported, no study that treats mass loss quantitatively has been carried out so far.

It is known that pressurized $\mathrm{N}_{2}$ gas suppresses mass loss of $\mathrm{Si}_{3} \mathrm{~N}_{4}$ ceramics during sintering. Thus, $\mathrm{N}_{2}$ gas at around $1 \mathrm{MPa}\left(10^{6} \mathrm{~Pa}\right)$ has become the predominant sintering condition for $\mathrm{Si}_{3} \mathrm{~N}_{4}$ ceramics in industry. Moreover, issues concerning mass loss and the formation of a heterogeneous surface layer during sintering have become closely guarded as an important "know how" of industry.

Non-pressurized $\mathrm{N}_{2}$ gas sintering may be a feasible low-

Now with Chair Professor, Department of Material Science, Faculty of Science, Chulalongkorn University, Thailand cost fabrication method for $\mathrm{Si}_{3} \mathrm{~N}_{4}$ ceramics. Therefore, we have been engaged in research to clarify the mechanism of the mass loss of $\mathrm{Si}_{3} \mathrm{~N}_{4}$ ceramics during sintering over the past four years. ${ }^{22)}-29$ )

As a result of our research, we found that $\mathrm{Si}_{3} \mathrm{~N}_{4}$ ceramics can be sintered without serious mass loss in air as well as in $0.1 \mathrm{MPa} \mathrm{N}_{2}$ gas. The instability during heat treatment and sintering of $\mathrm{Si}_{3} \mathrm{~N}_{4}$ and $\mathrm{Si}_{3} \mathrm{~N}_{4}$ ceramics is summarized and the sintering of $\mathrm{Si}_{3} \mathrm{~N}_{4}$ ceramics in $0.1 \mathrm{MPa} \mathrm{N} \mathrm{N}_{2}$ gas and in air is reported.

\section{Instability of $\mathrm{Si}_{3} \mathrm{~N}_{4}$ and $\mathrm{Si}_{3} \mathrm{~N}_{4}$ ceramics at} elevated temperature

2.1 Effect of temperature and pressure on the instability of $\mathrm{Si}_{3} \mathrm{~N}_{4}$

$\mathrm{Si}_{3} \mathrm{~N}_{4}$ ceramics are sintered in a $\mathrm{N}_{2}$ gas atmosphere furnace. The furnace is usually kept in vacuum from room temperature to around $1300 \mathrm{~K}$. This is followed by the introduction of $\mathrm{N}_{2}$ gas, heating and sintering at a set temperature of $2000-2100 \mathrm{~K}$. When the introduction of $\mathrm{N}_{2}$ gas is forgotten for some reason, not $\mathrm{Si}_{3} \mathrm{~N}_{4}$ but silicon metal is found in the position originally occupied by the $\mathrm{Si}_{3} \mathrm{~N}_{4}$ specimen after sintering. A researcher of $\mathrm{Si}_{3} \mathrm{~N}_{4}$ ceramics may have experienced this once or twice. This is the result of Reaction (1), namely, $\mathrm{Si}_{3} \mathrm{~N}_{4}$ decomposes to $\mathrm{Si}(\mathrm{l})$ and $\mathrm{N}_{2}(\mathrm{~g})$ at the sintering temperature in vacuum.

$$
\mathrm{Si}_{3} \mathrm{~N}_{4}(\mathrm{~s})=3 \mathrm{Si}(\mathrm{l})+2 \mathrm{~N}_{2}(\mathrm{~g})
$$

Here, (s), (1) and (g) indicate solid, liquid and gas, respectively.

$\mathrm{Si}_{3} \mathrm{~N}_{4}$ decomposes to $\mathrm{Si}(1)$ and $\mathrm{N}_{2}(\mathrm{~g})$ at $2151 \mathrm{~K}$ in normal $\left(10^{5} \mathrm{~Pa}\right) \mathrm{N}_{2}$ gas atmosphere, as seen in the JANAF thermochemical table. Greskovich and Prochazka calculated the thermodynamic equilibrium among $\mathrm{Si}_{3} \mathrm{~N}_{4}(\mathrm{~s}), \mathrm{Si}(1), \mathrm{N}_{2}(\mathrm{~g})$ and $\mathrm{Si}(\mathrm{g})$ for the reactions shown in Eqs. (1) and (2), and the result is shown in Fig. 1.13)

$$
\mathrm{Si}_{3} \mathrm{~N}_{4}(\mathrm{~s})=3 \mathrm{Si}(\mathrm{g})+2 \mathrm{~N}_{2}(\mathrm{~g})
$$

The following facts are understood from Fig. 1.

(1) The decomposition temperature of $\mathrm{Si}_{3} \mathrm{~N}_{4}(\mathrm{~s})$ in Reaction (1) becomes high with increasing $\mathrm{N}_{2}$ gas pressure. This relationship is shown by the line with a positive slope in the figure.

(2) $P_{\mathrm{Si}(\mathrm{g})}$ ((partial) pressure of Si gas) in Reaction 


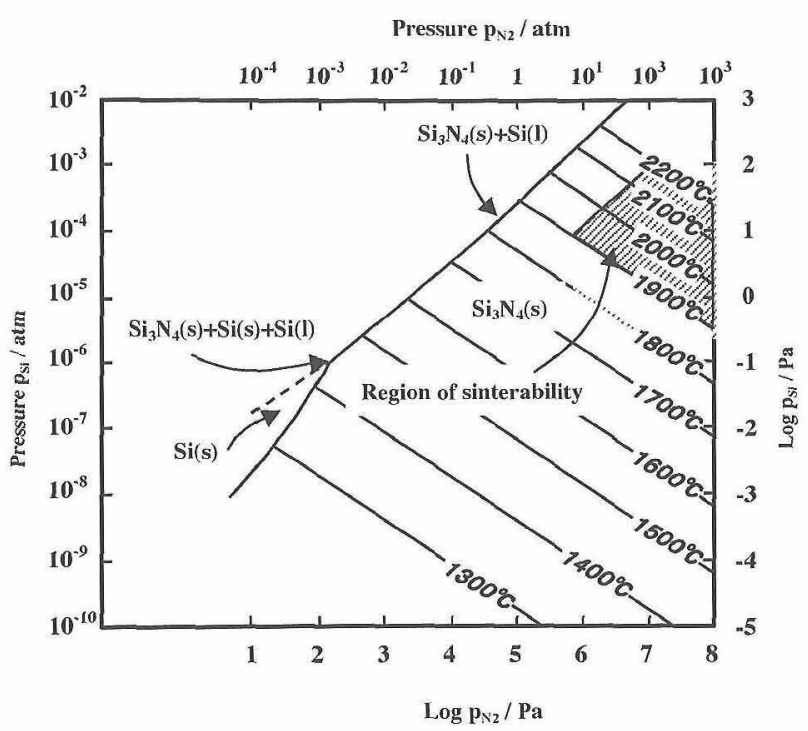

Fig. 1. Stability diagram for $\mathrm{Si}_{3} \mathrm{~N}_{4}$, where $\mathrm{Si}$ vapor is in equilibrium with $\mathrm{Si}_{3} \mathrm{~N}_{4}$ as a function of $\mathrm{N}_{2}$ pressure and temperature.

becomes high with increasing temperature and becomes low with increasing atmospheric $\mathrm{N}_{2}$ gas pressure. This relationship is shown by line with a negative slope in the figure. The absolute value of $P_{\mathrm{Si}(\mathrm{g})}$ is so low, being $P_{\mathrm{Si}(\mathrm{g})}=10 \mathrm{~Pa}$ even at $2173 \mathrm{~K}$ and $P_{\mathrm{N}_{2}}=10^{5} \mathrm{~Pa}\left(10^{5} \mathrm{~Pa} \fallingdotseq 1 \mathrm{~atm}\right)$.

The second fact is the reason why Si metal existed in the furnace when $\mathrm{Si}_{3} \mathrm{~N}_{4}$ was sintered in vacuum, that is, $\mathrm{Si}(1)$ did not vaporize as $\mathrm{Si}(\mathrm{g})$ because $P_{\mathrm{Si}(\mathrm{g})}$ is sufficiently low.

The hatched area in Fig. 1 is the recommended sintering conditions in the 80 th. The high sintering temperature above $2200 \mathrm{~K}$ might be due to the poor quality of the raw materials for sintering. Such high temperature required nitrogen gas pressures as high as $P_{\mathrm{N}_{2}}>10^{6} \mathrm{~Pa}$. Today, $\mathrm{Si}_{3} \mathrm{~N}_{4}$ powder for easy sintering and sintering additives having low melting temperature require approximately $1900 \mathrm{~K}$ to obtain dense $\mathrm{Si}_{3} \mathrm{~N}_{4}$ ceramics.

Consequently, Reaction (1), is rather than Reaction (2), is responsible for the instability of $\mathrm{Si}_{3} \mathrm{~N}_{4}$ at elevated temperature. Mass loss due to Reaction (2) was found to be negligible, because of the low gas pressure of $\mathrm{Si}$.

2.2. Reaction between $\mathrm{Si}_{3} \mathrm{~N}_{4}$ and $\mathrm{CO}$ gas

$\mathrm{Si}_{3} \mathrm{~N}_{4}$ ceramics are usually sintered in a carbon heater furnace filled with $\mathrm{N}_{2}$ gas. Carbon is also used as the material of a sagger. $\mathrm{Si}_{3} \mathrm{~N}_{4}$ decomposes to $\mathrm{SiC}(\mathrm{s})$ and $\mathrm{N}_{2}(\mathrm{~g})$ when it contacts with carbon at elevated temperatures, as shown in Eq. (3).

$$
\mathrm{Si}_{3} \mathrm{~N}_{4}(\mathrm{~s})+3 \mathrm{C}(\mathrm{s})=3 \mathrm{SiC}(\mathrm{s})+2 \mathrm{~N}_{2}(\mathrm{~g})
$$

This reaction is not the main reaction of $\mathrm{Si}_{3} \mathrm{~N}_{4}$ with $\mathrm{C}$, because specimens are prevented from direct contact with carbon during production as well as the experiment. One phenomenon that is usually observed is that $\mathrm{SiC}(\mathrm{s})$ layer is generated on the surface of the carbon sagger after using it many times. That is due to the following Reactions (4) and (5).

$$
\begin{aligned}
& 2 \mathrm{Si}_{3} \mathrm{~N}_{4}(\mathrm{~s})+3 \mathrm{CO}(\mathrm{g})=3 \mathrm{SiC}(\mathrm{s})+3 \mathrm{SiO}(\mathrm{g})+4 \mathrm{~N}_{2}(\mathrm{~g}) \\
& \mathrm{SiO}(\mathrm{g})+2 \mathrm{C}(\mathrm{s})=\mathrm{SiC}(\mathrm{s})+\mathrm{CO}(\mathrm{g})
\end{aligned}
$$

That is, $\mathrm{SiO}(\mathrm{g})$ generated by Reaction (4) reacts with carbon and regenerates $\mathrm{CO}(\mathrm{g})$ as shown in Eq. (5). From the material balance, Reaction (4) plus (5) is equal to Reaction (3). There are two sources of $\mathrm{CO}(\mathrm{g})$ for generating Reac-

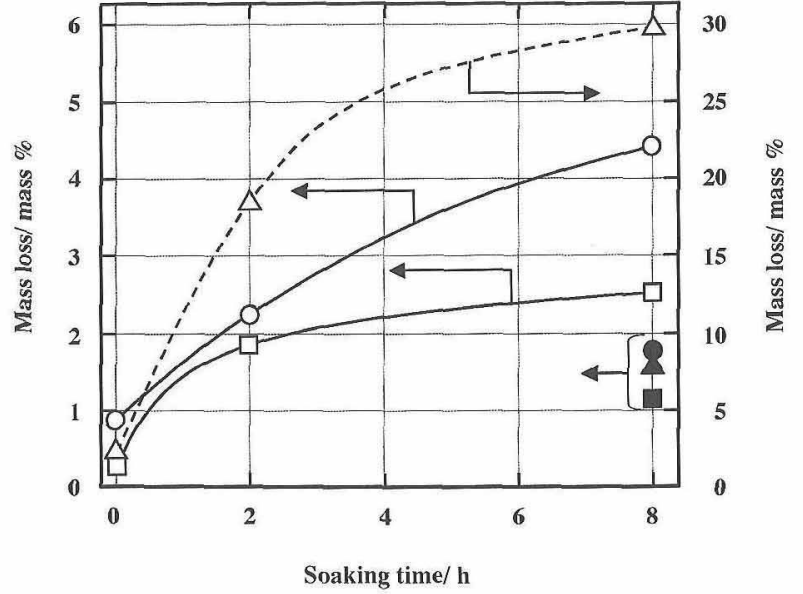

Fig. 2. Mass loss of $\mathrm{Si}_{3} \mathrm{~N}_{4}$ powder compacts heat-treated at $2023 \mathrm{~K}$ under 0.1 and $1 \mathrm{MPa} \mathrm{N}_{2}$ in $\mathrm{C}$ and $\mathrm{BN}$ saggers as a function of soaking time. $0.1 \mathrm{MPa}(\square)$ and $1 \mathrm{MPa}(\square)$ with $\mathrm{Si}_{3} \mathrm{~N}_{4}$ powder bed in $\mathrm{BN}$ sagger, 0.1 $\mathrm{MPa}(\mathrm{O})$ and $1 \mathrm{MPa}(O)$ without powder bed in $\mathrm{BN}$ sagger, $0.1 \mathrm{MPa}(\triangle)$ and $1 \mathrm{MPa}(\Delta)$ with $\mathrm{C}$ powder bed in $\mathrm{C}$ sagger.

tion (4): one is oxygen impurity in the nitrogen gas used. Industrially pure nitrogen gas, grade $\mathrm{B}$, contains $0.05 \mathrm{~Pa}$ oxygen. When $\mathrm{O}_{2}(\mathrm{~g})$ reacts with $\mathrm{C}(\mathrm{s})$ in the furnace, $0.1 \mathrm{~Pa}$ $\mathrm{CO}(\mathrm{g})$ is generated in the furnace. The $\mathrm{SiO}(\mathrm{g})$ generated from Reaction (10), mentioned later in 2.3, also generates $\mathrm{CO}(\mathrm{g})$ via Reaction (5).

The experimental results of the Reaction between $\mathrm{Si}_{3} \mathrm{~N}_{4}$ (s) and $\mathrm{CO}(\mathrm{g})$ are shown in Fig. $2{ }^{24)}$ When $\mathrm{Si}_{3} \mathrm{~N}_{4}$ compacts are heat-treated in the presence of carbon powder, about 20 mass $\%$ of the mass loss occurs at $2023 \mathrm{~K}$ and $2 \mathrm{~h}\left(-\Delta^{-}\right)$. The mass loss is due to Reactions (4) and (5). Then, the same specimens are set in a BN sagger so that the reaction of $\mathrm{SiO}(\mathrm{g})$ generated by Eq. (4) with carbon (Reaction (5)) will be controlled. Mass loss decreased to 4.4 mass\% even after heat treatment for $8 \mathrm{~h}(-\mathrm{O}-)$. Mass loss decreased to 2.5 mass $\%$ at $8 \mathrm{~h}$ when the same specimens were packed in a mixed powder of $\mathrm{Si}_{3} \mathrm{~N}_{4}$ and $\mathrm{BN}(-\square-)$. These heat treatments were performed under $0.1 \mathrm{MPa}(\fallingdotseq 1 \mathrm{~atm}) \mathrm{N}_{2}$ gas. Mass loss decreased noticeably when $P_{\mathrm{N}_{2}(\mathrm{~g})}$ was increased to $1 \mathrm{MPa}$ independent of the kind of sagger and the packing powder conditions. The following facts are concluded from the chemical analysis of oxygen and carbon and the X-ray diffraction data of the heat-treated specimens.

(1) $\mathrm{Si}_{3} \mathrm{~N}_{4}(\mathrm{~s})$ reacts with $\mathrm{CO}(\mathrm{g})$ very rapidly.

(2) By disturbing the reaction of $\mathrm{SiO}(\mathrm{g})$ with $\mathrm{C}(\mathrm{s})$, the regeneration of $\mathrm{CO}(\mathrm{g})$ is controlled. However, $\mathrm{CO}(\mathrm{g})$ diffuses into the sagger through the gap of the sagger and reacts with $\mathrm{Si}_{3} \mathrm{~N}_{4}(\mathrm{~s})$.

(3) The packing powder, which is the mixture of silicon nitride and $\mathrm{BN}$, controls the diffusion of $\mathrm{SiO}(\mathrm{g})$ to the outside of the sagger and stops the access of $\mathrm{CO}(\mathrm{g})$ to the specimen by pre-reacting with $\mathrm{CO}(\mathrm{g})$ diffusing into the sagger.

Consequently, though $\mathrm{Si}_{3} \mathrm{~N}_{4}(\mathrm{~s})$ reacts easily with $\mathrm{CO}(\mathrm{g})$, the reaction is controlled practically by means of the sagger and packing powders.

\subsection{Reaction between $\mathrm{Si}_{3} \mathrm{~N}_{4}$ and oxygen}

Silicon nitride and $\mathrm{Si}_{3} \mathrm{~N}_{4}$ ceramics are easily oxidized in air at elevated temperatures above $1300 \mathrm{~K}$. The oxidation mechanisms are passive oxidation in the atmosphere of $P_{\mathrm{O}_{2}} \geqq 10^{2} \mathrm{~Pa}$ and active oxidation at less than $10^{2} \mathrm{~Pa}$, as shown in Eqs. (6) and (7). 


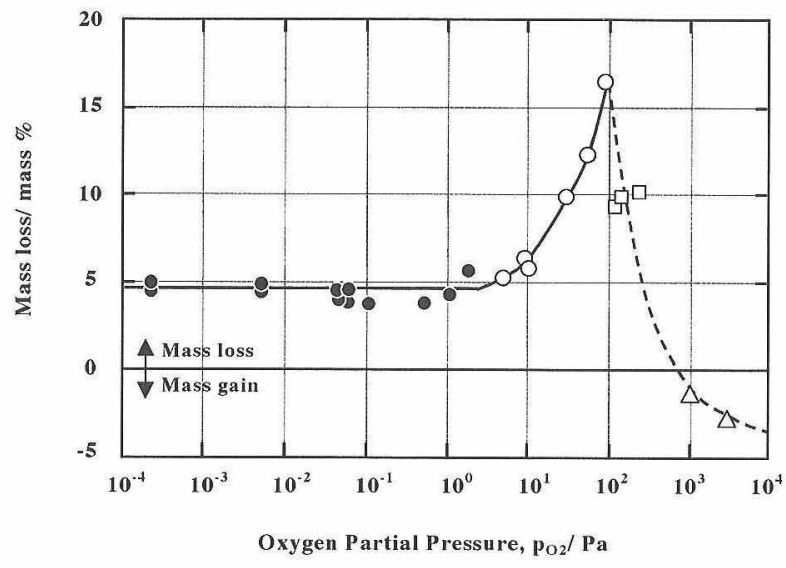

Fig. 3. Mass loss of $\mathrm{Si}_{3} \mathrm{~N}_{4}$ ceramics sintered at $1923 \mathrm{~K}$ for $2 \mathrm{~h}$ as a function of oxygen partial pressure, $P_{\mathrm{O}_{2}}$ under $\mathrm{N}_{2}$ gas flow of 0.1 $\mathrm{MPa}$. $\triangle$ mass loss in the region of passive oxidation, $\square$ mass loss in the transition region from passive to active oxidation, $\bigcirc$ mass loss in the region of active oxidation, mass loss in the region of vaporization.

$$
\begin{aligned}
& \mathrm{Si}_{3} \mathrm{~N}_{4}(\mathrm{~s})+3 \mathrm{O}_{2}(\mathrm{~g})=3 \mathrm{SiO}_{2}(\mathrm{l})+2 \mathrm{~N}_{2}(\mathrm{~g}) \\
& 2 \mathrm{Si}_{3} \mathrm{~N}_{4}(\mathrm{~s})+3 \mathrm{O}_{2}(\mathrm{~g})=6 \mathrm{SiO}(\mathrm{g})+4 \mathrm{~N}_{2}(\mathrm{~g})
\end{aligned}
$$

In the sintering of $\mathrm{Si}_{3} \mathrm{~N}_{4}$ ceramics in a carbon furnace, the oxidation of $\mathrm{Si}_{3} \mathrm{~N}_{4}$ ceramics scarcely occurs because $P_{\mathrm{O}_{2}}$ is as low as $10^{-24} \mathrm{~Pa} .{ }^{22}$ ) When $\mathrm{Si}_{3} \mathrm{~N}_{4}$ is sintered using a Mo- or W-heater continuous furnace, however, much amount of oxygen than that in pure nitrogen gas used will exist in the furnace. Then, sintering in flowing $\mathrm{N}_{2}$ gas with various oxygen partial pressures was performed. ${ }^{26)}$ In this experiment, $\mathrm{N}_{2}$ gas had to be introduced to controll $P_{\mathrm{O}_{2}}$. Otherwise, $P_{\mathrm{O}_{2}}$ less than $1 \mathrm{~Pa}$ could not be attained by the diffusion of air from the outside.

The relationship between $P_{\mathrm{O}}$, in $\mathrm{N}_{2}$ gas and mass loss is shown in Fig. 3. When $P_{\mathrm{O}_{2}}>10^{3} \mathrm{~Pa}$, passive oxidation obviously occurs because the mass increases. When $P_{0}$, is between $10^{2} \mathrm{~Pa}$ and $10^{3} \mathrm{~Pa}$, oxidations both passive and active occur, based on the appearance of the specimens and X-ray diffraction data, though mass loss increased. Though porous bubbles of $\mathrm{SiO}_{2}$ was on the surface, the inside of the specimens was sintered without porosity. Mass loss decreased quickly when $P_{\mathrm{O}_{2}}$ was reduced to less than $10^{2} \mathrm{~Pa}$. However, the mass loss does not decrease to less than about 5 mass\% even when $P_{\mathrm{O}_{2}}$ is less than $10^{\circ} \mathrm{Pa}$. That is, there must be some other mass loss reactions from the active oxidation in flowing $\mathrm{N}_{2}$ gas atmosphere of $P_{\mathrm{O}_{2}}<10^{\circ} \mathrm{Pa}$.

Two reactions were observed in flowing $\mathrm{N}_{2}(\mathrm{~g})$ with $P_{\mathrm{O}_{2}}<10^{\circ} \mathrm{Pa}$. One is Reaction (10), which will be explained in 2.4. The other is Reaction (2), which was mentioned in 2.1 as the reaction of little importance from the standpoint of mass loss. The contribution of Reaction (2) to mass loss in flowing $\mathrm{N}_{2}$ gas will be explained in 2.5 .

Therefore, oxidation is not the direct cause of mass loss of $\mathrm{Si}_{3} \mathrm{~N}_{4}$ ceramics under the condition of $P_{\mathrm{O}_{2}}<10^{\circ} \mathrm{Pa}$ in this experiment.

2.4 Reaction between $\mathrm{Si}_{3} \mathrm{~N}_{4}$ with glass phase component

Silicon nitride ceramics are consolidated by liquid-phase sintering with the addition of $\mathrm{Al}_{2} \mathrm{O}_{3}$ and $\mathrm{Y}_{2} \mathrm{O}_{3}$ or $\mathrm{MgO}$ as sintering additives. A glass phase composed of $\mathrm{SiO}_{2}$, which covers the surface of $\mathrm{Si}_{3} \mathrm{~N}_{4}$ particle, and the additives mentioned above fill grain boundaries at elevated temperature. The free energy of the glass phase, which is composed of several components, can be calculated in general, though it

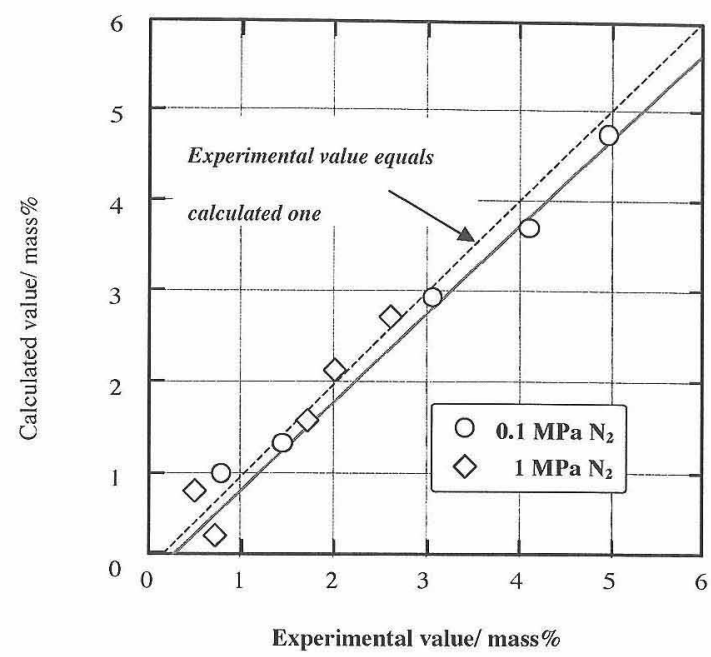

Fig. 4. Relationship between experimental values of mass loss and calculated ones on the basis of an assumption that all of the oxygen loss occurred via Reaction (10), for the samples sintered at $2023 \mathrm{~K}$ under 0.1 and $1 \mathrm{MPa} \mathrm{N}_{2}$ in $\mathrm{BN}$ sagger without powder bed.

is difficult to determine the free energy of the grain-boundary glass phase because its composition changes with the heating process. Then, the stability of the grain-boundary glass phase was evaluated from the stability of each component. Magnesium oxide and $\mathrm{SiO}_{2}(1)$ easily decompose to $\mathrm{Mg}(\mathrm{g}), \mathrm{SiO}(\mathrm{g})$ and $\mathrm{O}_{2}(\mathrm{~g})$ via the reactions shown in Eqs. (8) and (9). On the other hand, $\mathrm{Al}_{2} \mathrm{O}_{3}(\mathrm{~s})$ and $\mathrm{Y}_{2} \mathrm{O}_{3}(\mathrm{~s})$ are stable, based on thermodynamic calculations. ${ }^{22)}$

$$
\begin{aligned}
& 2 \mathrm{MgO}(\mathrm{s})=2 \mathrm{Mg}(\mathrm{g})+\mathrm{O}_{2}(\mathrm{~g}) \\
& 2 \mathrm{SiO}_{2}(\mathrm{l})=2 \mathrm{SiO}(\mathrm{g})+\mathrm{O}_{2}(\mathrm{~g})
\end{aligned}
$$

When $\mathrm{SiO}_{2}-\mathrm{Al}_{2} \mathrm{O}_{3}-\mathrm{Y}_{2} \mathrm{O}_{3}$ glass was heat-treated in $\mathrm{N}_{2}$ atmosphere at $2023 \mathrm{~K}$, only the quantity of $\mathrm{Si}$ ion decreased. The $\mathrm{Si}$ ion was thought to be vaporized as $\mathrm{SiO}(\mathrm{g}) .^{22)}$

The reaction between $\mathrm{Si}_{3} \mathrm{~N}_{4}(\mathrm{~s})$ and the glass phase is important in the sintering of $\mathrm{Si}_{3} \mathrm{~N}_{4}$ ceramics. Reactions (10)(13) are considered to be the causes of the mass loss of $\mathrm{Si}_{3} \mathrm{~N}_{4}$ ceramics when $\mathrm{Al}_{2} \mathrm{O}_{3}$ and $\mathrm{Y}_{2} \mathrm{O}_{3}$ are used as sintering additives.

$$
\begin{aligned}
& \mathrm{Si}_{3} \mathrm{~N}_{4}(\mathrm{~s})+3 \mathrm{SiO}_{2}(\mathrm{l})=6 \mathrm{SiO}(\mathrm{g})+2 \mathrm{~N}_{2}(\mathrm{~g}) \\
& \mathrm{Si}_{3} \mathrm{~N}_{4}(\mathrm{~s})+\mathrm{SiO}_{2}(\mathrm{l})=2 \mathrm{SiO}(\mathrm{g})+2 \mathrm{Si}(\mathrm{l})+2 \mathrm{~N}_{2}(\mathrm{~g}) \\
& \mathrm{Si}_{3} \mathrm{~N}_{4}(\mathrm{~s})+\mathrm{Al}_{2} \mathrm{O}_{3}(\mathrm{~s})=3 \mathrm{SiO}(\mathrm{g})+2 \mathrm{AIN}(\mathrm{s})+\mathrm{N}_{2}(\mathrm{~g}) \\
& \mathrm{Si}_{3} \mathrm{~N}_{4}(\mathrm{~s})+\mathrm{Y}_{2} \mathrm{O}_{3}(\mathrm{~s})=3 \mathrm{SiO}(\mathrm{g})+2 \mathrm{YN}(\mathrm{s})+\mathrm{N}_{2}(\mathrm{~g})
\end{aligned}
$$

$P_{\mathrm{SiO}(\mathrm{g})}$ calculated from the thermodynamic equilibrium in Reaction (10) is the highest among those in Reactions (10)-(13) at the same $\mathrm{N}_{2}$ gas pressure at $2000-2100 \mathrm{~K}$. When Reaction (10) occurs, oxygen content in the specimen decreases. Mass loss corresponding to the decrease in oxygen content can be calculated from Eq. (10). On the other hand, the mass of specimens is measured precisely before and after sintering.24),25) Comparison of both values showed very good coincidence, as shown in Fig. 4. The major mass loss reaction is, therefore, concluded to be Reaction (10) from the experiment. ${ }^{24), 25)}$

In Reaction (10), $P_{\mathrm{SiO}(\mathrm{g})}$ at thermodynamic equilibrium is related to $P_{\mathrm{N}_{2}(\mathrm{~g})}$ as shown in Eq. (14) ${ }^{24), 25)}$

$$
P_{\mathrm{SiO}(\mathrm{g})} \propto\left(P_{\mathrm{N}_{2}(\mathrm{~g})}\right)^{-1 / 3}
$$

That is, $P_{\mathrm{SiO}(\mathrm{g})}$ is related to $P_{\mathrm{N}_{2}(\mathrm{~g})}$ by the slope of $-1 / 3$ in the 


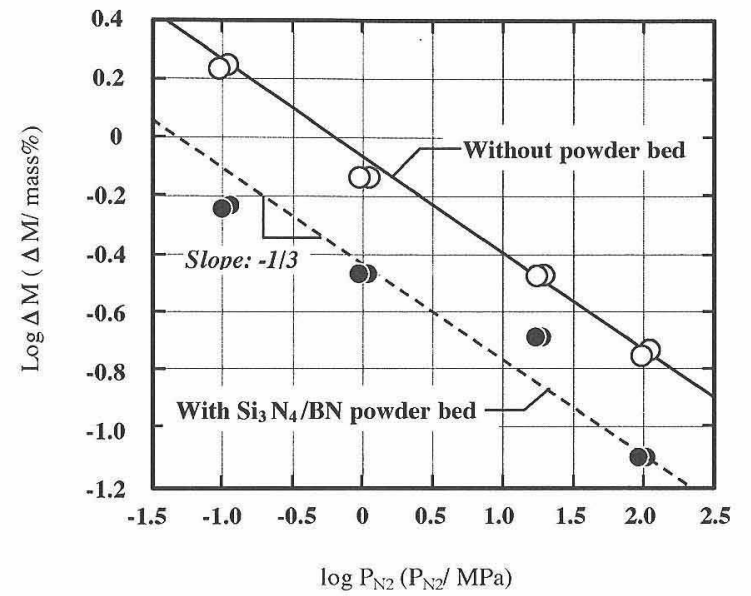

Fig. 5. Relationship between $\log \Delta M$ and $\log P_{\mathrm{N}_{2}}$ for samples sintered at $2023 \mathrm{~K}$ for $2 \mathrm{~h}$ under 0.1 to $100 \mathrm{MPa} \mathrm{N}_{2}$ in $\mathrm{BN}$ sagger.

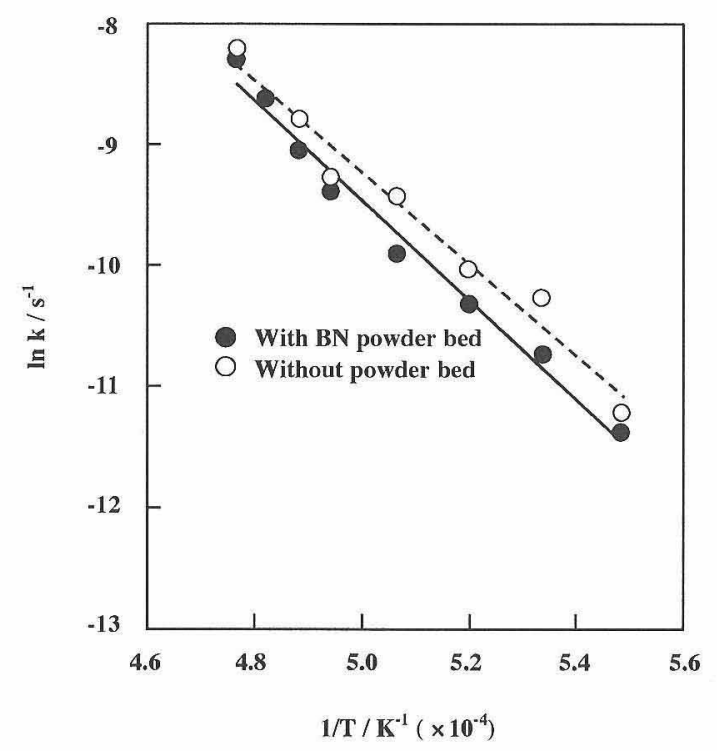

Fig. 6. Arrhenius plot of mass loss per unit time (k) for the sample sintered under $0.1 \mathrm{MPa} \mathrm{N}_{2}$ in $\mathrm{BN}$ sagger.

$\log / \log$ scale plot. The relationship between mass loss and $P_{\mathrm{N}_{2}(\mathrm{~g})}$ of same specimens as those in Fig. 4 and sintered at $0.1-100 \mathrm{MPa}$ of $P_{\mathrm{N}_{2}(\mathrm{~g})}$ is shown in Fig. 5. Figure 5 shows that the logarithmic value of the mass loss rate of $\mathrm{Si}_{3} \mathrm{~N}_{4}$ ceramics is proportional to $-1 / 3$ of the logarithmic value of $P_{\mathrm{SiO}(\mathrm{g})}$. As a result, mass loss rate is proportional to $P_{\mathrm{SiO}(\mathrm{g})}$. Specimens were set in a BN sagger and there was no big gap between the lid and the belly of the sagger in the experiment. 24),25) The evaporation rate of $\mathrm{SiO}(\mathrm{g})$ from $\mathrm{Si}_{3} \mathrm{~N}_{4}$ ceramics will be controlled by the rates of diffusion of $\mathrm{Si}$ and $\mathrm{O}$ ions in the grain boundaries, $\mathrm{SiO}(\mathrm{g})$ vaporization from the surface of specimen and $\mathrm{SiO}(\mathrm{g})$ diffusion through the gap of the sagger. Figure 5 suggests that the rate-controlling step is the diffusion rate of $\mathrm{SiO}(\mathrm{g})$ through the gap of the sagger. High $\mathrm{N}_{2}$ gas pressure in the furnace effectively suppresses the mass loss rate during sintering.

Figure 6 shows the relationship between mass loss and heat-treatment temperature of $\mathrm{Si}_{3} \mathrm{~N}_{4}$ ceramics under almost the same experimental conditions as Fig. 4. ${ }^{28)}$ The mass loss mechanism was confirmed to be the same as that shown

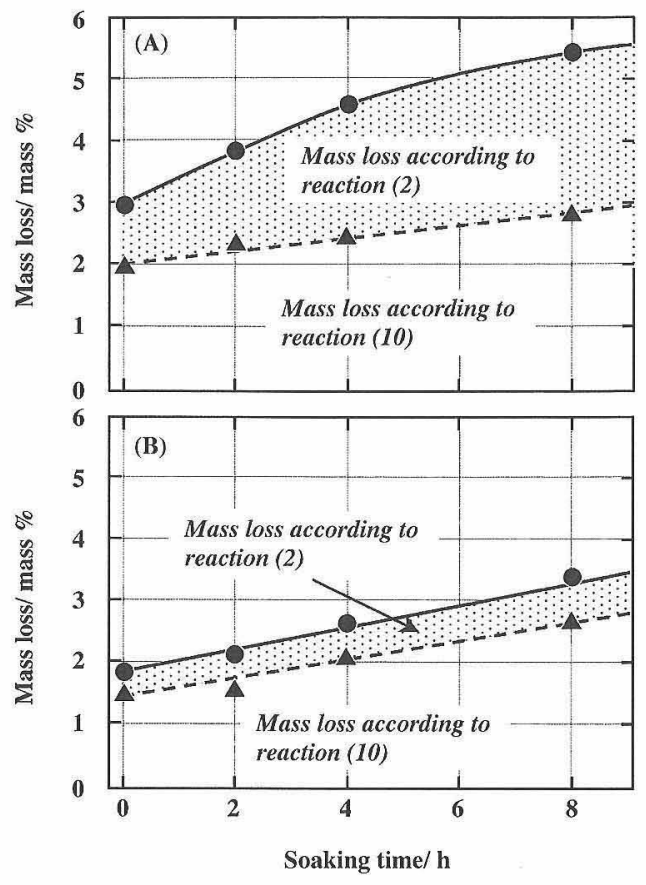

Fig. 7. Mass loss as a function of soaking time for the sample sintered at $1923 \mathrm{~K}$ in oxygen pressure of $5.0 \times 10^{-2} \mathrm{~Pa}$ under flowing $\mathrm{N}_{2}$ gas (A) without a covering, (B) with $\mathrm{Si}_{3} \mathrm{~N}_{4}$ packing powder in an Mo crucible.

Experimental mass loss value, $\mathbf{\Delta}$ calculated mass loss value on the basis of the assumption that all of the mass loss occurred via Reaction (10).

in Reaction (10). The slope of the Arrhenius plot of the mass loss is almost the same as that of $P_{\mathrm{SiO}(\mathrm{g})}$. It is seen from the figure that the mass loss rate decreases by one order of magnitude when the heat-treatment temperature decreases by $30 \mathrm{~K}$.

The dependence of $P_{\mathrm{SiO}(g)}$ upon the temperature in Reaction (11) is larger than that in Reaction (10), though the details of the thermodynamic calculation are not shown here. Therefore, Reaction (11) may become the main mass loss reaction at temperatures above $2146 \mathrm{~K}$. When Reaction (11) occurs, $\mathrm{Si}$ metal will precipitates in $\mathrm{Si}_{3} \mathrm{~N}_{4}$ ceramics and $\mathrm{SiO}(\mathrm{g})$ will vaporize. This is evidenced by the observation that $\mathrm{Si}$ metal is sometimes observed in $\mathrm{Si}_{3} \mathrm{~N}_{4}$ ceramics sintered at very high temperatures.

Consequently, the following are summarized;

(1) The major mass loss reaction of $\mathrm{Si}_{3} \mathrm{~N}_{4}$ ceramics during sintering is Reaction (10).

(2) The mass loss rate depends on $\mathrm{N}_{2}$ gas pressure, as shown by Eq. (14).

(3) The mass loss rate decreases with decreasing heattreatment temperature, as shown in Fig. 6.

It should be noted that the mass loss reaction of $\mathrm{Si}_{3} \mathrm{~N}_{4}$ ceramics using $\mathrm{MgO}$ or $\mathrm{MgAl}_{2} \mathrm{O}_{4}$ as sintering additives should be performed hereafter, because $\mathrm{Mg}(\mathrm{g})$ has high vapor pressure, as mentioned in 2.4 .

\subsection{Effect of gas flow}

Figure 7 shows mass loss as a function of soaking time for the sample sintered at $1923 \mathrm{~K}$ in $P_{\mathrm{O}_{2}}(\mathrm{~g})=5.0 \times 10^{-2} \mathrm{~Pa}$ under flowing $\mathrm{N}_{2}$ gas (A) without a covering, (B) with $\mathrm{Si}_{3} \mathrm{~N}_{4}$ packing powder in a Mo crucible. Gas flow strongly influences mass loss whether it flows directly on the surface of the specimen or the surface of the specimen is covered from the flowing gas.

It was mentioned in 2.1 that Reaction (2) is not im- 
portant. However, as shown in Fig. 7, Reaction (2) cannot be neglected when $\mathrm{N}_{2}$ gas flows directly on the surface of the specimen; that is, since $\mathrm{Si}(\mathrm{g})$ on the surface of the specimen is removed from the surface by the flowing $\mathrm{N}_{2}$ gas, $P_{\mathrm{Si}(\mathrm{g})}$ decreases to a value below the equilibrium value and the reaction proceeds from left to right.

\subsection{Packing powder}

$\mathrm{Si}_{3} \mathrm{~N}_{4}$ specimens are sometimes sintered in a packing powder. The objective of using the packing powder is to prevent the formation of a surface layer that differs in morphology and properties from the inside part of the specimen. The formation mechanism of the surface layer has not yet been reported in detail. Yokoyama and Wada reported that the surface layer is generated by Reaction (10).24),25)

The vaporization of $\mathrm{SiO}(\mathrm{g})$ from specimens is controlled by burying specimens in packing powder. One of the effects of the packing powder is to disturb the diffusion of $\mathrm{SiO}(\mathrm{g})$ to outside of the sagger, as mentioned in 2.2. This effect is produced regardless of the kind of powder used.

Another more effective process is to create an $\mathrm{SiO}(\mathrm{g})$ atmosphere when $\mathrm{Si}_{3} \mathrm{~N}_{4}$ powder with $\mathrm{SiO}_{2}$ layer is used as the packing powder. For example, the mass of the specimen increases in the early stage of sintering when $\mathrm{Si}_{3} \mathrm{~N}_{4}$ is used as the packing powder (Fig. 6 of Ref. 24). However, since the amount of $\mathrm{SiO}_{2}$ on the surface of $\mathrm{Si}_{3} \mathrm{~N}_{4}$ powder is small, the effect is not sustained for a long time. ${ }^{24)}$

The third effect of the $\mathrm{Si}_{3} \mathrm{~N}_{4}$ packing powder is to prevent the reaction of $\mathrm{CO}(\mathrm{g})$ with the specimen; that is, the $\mathrm{Si}_{3} \mathrm{~N}_{4}$ packing powder reacts beforehand with $\mathrm{CO}(\mathrm{g})$ that diffuses into the sagger through the gap. ${ }^{24)}$

It was reported that $\mathrm{AlN}$ sucked out $\mathrm{SiO}_{2}$ from the grain boundary of $\mathrm{Si}_{3} \mathrm{~N}_{4}$ ceramics. ${ }^{30}$ ) The mechanism may be that AlN reacts with $\mathrm{SiO}(\mathrm{g})$, thus decreasing the $P_{\mathrm{Si}(\mathrm{g})}$ around specimen. ${ }^{29)}$

Such operations as burying and taking off specimens in and from the packing powder are not welcome from the operation time and the dusty environment. Therefore, $\mathrm{N}_{2}$ gas pressure sintering to suppress Reaction (10) has been used in industry.

\section{Sintering of $\mathrm{Si}_{3} \mathrm{~N}_{4}$ ceramics in $0.1 \mathrm{MPa} \mathrm{N} \mathrm{N}_{2}$ gas}

The science of $\mathrm{Si}_{3} \mathrm{~N}_{4}$ ceramics, especially the sintering technology, has progressed greatly in the 1980s. The morphology in which $\mathrm{Si}_{3} \mathrm{~N}_{4}$ grains have a large aspect ratio has been investigated to attain a large $K_{\text {IC }}$ and a high mechanical strength. To attain such properties, sintering temperatures above $2000 \mathrm{~K}$, preferably above $2100 \mathrm{~K}$, have been recommended. Sintering has been performed at $1 \mathrm{MPa} \mathrm{N}_{2}$ gas to suppress Reaction (10). From the standpoint of sintering cost, normal gas pressure sintering is preferable in the future. To this end, decreasing the sintering temperature and using packing powder are efficient ways, as discussed in 2.5 and 2.6. When the mixed powder of $\mathrm{Si}_{3} \mathrm{~N}_{4}$ and $\mathrm{SiO}_{2}$ is used as packing powder, $\mathrm{SiO}(\mathrm{g})$ atmosphere is sustained for a long time. ${ }^{27)}$ In this case, specimens are not essentially packed in the powder. The role of the mixed powder is to create a $\mathrm{SiO}(\mathrm{g})$ atmosphere in the sagger. Then, when some amount of the mixed powder is present in the sagger in the form of pellets, mass loss of specimens as a result of Reaction (10) is controlled. ${ }^{27)}$ Thus, the operation time is shortened and dusty environment problem is solved.

Only a few papers have reported the sintering of $\mathrm{Si}_{3} \mathrm{~N}_{4}$ ceramics with excellent mechanical properties at low temperature and in normal $\mathrm{N}_{2}$ pressure in the 1980s and the 1990s. Regarding mass loss, decreasing the sintering temperature by $30 \mathrm{~K}$ (Fig. 6) is comparable to increasing the $\mathrm{N}_{2}$ pressure by one order of magnitude (Fig. 5). As far as the mass loss is concerned, it will be negligible even if the $\mathrm{Si}_{3} \mathrm{~N}_{4}$ ceramics are sintered without packing powder when the sintering temperature is as low as $1900 \mathrm{~K}$. Detailed research on the sintering of $\mathrm{Si}_{3} \mathrm{~N}_{4}$ ceramics at low temperature should be performed hereafter.

\section{Sintering of $\mathrm{Si}_{3} \mathrm{~N}_{4}$ ceramics in air furnace}

Sintering of $\mathrm{Si}_{3} \mathrm{~N}_{4}$ ceramics in an air furnace has never been attempted so far. The authors have noted that $\mathrm{Si}_{3} \mathrm{~N}_{4}$ ceramics must be sintered in an air after the research which are reviewed in 2.21)-29) Air is composed of $80 \% \mathrm{~N}_{2}$ gas and $20 \% \mathrm{O}_{2}$ gas $\left(P_{\mathrm{O}_{2}}=2 \times 10^{4} \mathrm{~Pa}\right)$. The important fact is that $P_{\mathrm{N}_{2}}$ $\equiv 8 \times 10^{4} \mathrm{~Pa}$; that is, $\mathrm{Si}_{3} \mathrm{~N}_{4}$ does not decompose via Reaction (1) up to $2100 \mathrm{~K}$, as long as $P_{\mathrm{N}_{2}}=8 \times 10^{4} \mathrm{~Pa}$. The problem is the oxygen content in air, i.e., $P_{\mathrm{O}_{2}}=2 \times 10^{4} \mathrm{~Pa}$. Silicon nitride ceramics change to $\mathrm{SiO}_{2}$ by passive oxidation, as shown in Reaction (6), when it is sintered in air. Therefore, the $\mathrm{Si}_{3} \mathrm{~N}_{4}$ specimen must be isolated from air as much as possible.

Then, $\mathrm{Si}_{3} \mathrm{~N}_{4}$ ceramics are sintered in a sagger. Considering the anti-oxidation property and high temperature resistance, $\mathrm{Al}_{2} \mathrm{O}_{3}$ ceramics are considered to be one of the candidate materials for the sagger. When $\mathrm{Si}_{3} \mathrm{~N}_{4}$ ceramics are sintered in the sagger, there are two different sources of oxygen: one is the oxygen in the sagger, the other is the oxygen diffusing into the sagger through a gap. The amount of oxygen calculated from the volume of the sagger is not so large. ${ }^{1)}$ When the sagger is filled with $\mathrm{Si}_{3} \mathrm{~N}_{4}$ powder, the powder consumes oxygen in the sagger via Reaction (6) and then, when $P_{\mathrm{O}_{2}}$ in the sagger decreases to below $10^{2} \mathrm{~Pa}$, Reaction (7) occurs. Once Reaction (7) occurs, three moles of $\mathrm{O}_{2}(\mathrm{~g})$ changes to $6 \mathrm{~mol}$ of $\mathrm{SiO}(\mathrm{g})$ and $4 \mathrm{~mol}$ of $\mathrm{N}_{2}(\mathrm{~g})$. Therefore, once active oxidation occurs, the generated gas increases in volume and flows out through the gap of the sagger, thereby decreasing the oxygen partial pressure in the sagger and disturbing the diffusion of air from outside of the sagger. After most of the oxygen in the sagger has reacted with $\mathrm{Si}_{3} \mathrm{~N}_{4}$, the generated gas flow stops and air will again diffuse into the sagger. However, since the sagger is filled with $\mathrm{Si}_{3} \mathrm{~N}_{4}$ powder, oxygen diffusing into the sagger reacts with $\mathrm{Si}_{3} \mathrm{~N}_{4}$ powder near the gap of the sagger and these will not reach the $\mathrm{Si}_{3} \mathrm{~N}_{4}$ specimen.

Experiments based on the above consideration demonstrated that homogeneous $\mathrm{Si}_{3} \mathrm{~N}_{4}$ ceramics can be sintered without much mass loss. ${ }^{31)}$

\section{Future work}

The science and technology of $\mathrm{Si}_{3} \mathrm{~N}_{4}$ and $\mathrm{SiAlON}$ ceramics have progressed rapidly over the past 30 years. However, we have not yet gotten sufficient harvest from the standpoint of the industrial applications. Most of the research performed by academic organizations has been aimed at attaining ultra high strength and ultra large $K_{1 \mathrm{C}}$, neglecting process cost in the last 15 years. Those researches have worth in the investigation of the frontier. Materials having excellent properties based on the advanced technologies such as hot-pressing, hot-isostatic-pressing and complicated processes, however, have not found many applications.

Considering these facts, the research to produce $\mathrm{Si}_{3} \mathrm{~N}_{4}$ ceramics with moderate properties and at a cheap cost, for example, sintering at normal $\mathrm{N}_{2}$ pressure or sintering in air, must be one of the research themes conducted. Research to reduce the cost of $\mathrm{Si}_{3} \mathrm{~N}_{4}$ ceramics on the whole, and not only the sintering cost, should be performed in the future.

\section{Summary}

The instabilities of $\mathrm{Si}_{3} \mathrm{~N}_{4}$ and $\mathrm{Si}_{3} \mathrm{~N}_{4}$ ceramics during sintering were reviewed. As a result of the instabilities, $\mathrm{Si}_{3} \mathrm{~N}_{4}$ and $\mathrm{Si}_{3} \mathrm{~N}_{4}$ ceramics lose their masses or decompose. The major mass loss reaction of $\mathrm{Si}_{3} \mathrm{~N}_{4}$ ceramics is as follows. 


$$
\mathrm{Si}_{3} \mathrm{~N}_{4}(\mathrm{~s})+3 \mathrm{SiO}_{2}(\mathrm{l})=6 \mathrm{SiO}(\mathrm{g})+2 \mathrm{~N}_{2}(\mathrm{~g})
$$

Regarding mass loss, decreasing the sintering temperature by $30 \mathrm{~K}$ corresponds to increasing $\mathrm{N}_{2}$ pressure in the furnace by one order of magnitude. By being well acquired with the mass loss phenomena, sintering of $\mathrm{Si}_{3} \mathrm{~N}_{4}$ ceramics in $\mathrm{N}_{2}$ gas at $0.1 \mathrm{MPa}$ or air will become the candidate conditions for the mass production of $\mathrm{Si}_{3} \mathrm{~N}_{4}$ ceramics. The research to reduce the total cost of $\mathrm{Si}_{3} \mathrm{~N}_{4}$ ceramics was discussed.

Acknowledgement This review is based on the results of five years of research with Dr. Kazushige Yokoyama and Mr. Tomoya Hattori. Both were students of Toyota Technological Institute. The research was performed in Toyota CRDL, which is a joint graduate school with TTI. The reviewer expresses his sincere thanks to both gentlemen and both organizations. The review was written in Chulalongkorn University, Bangkok by the author, who is a Chair Professor of the Faculty of Science of the University.

\section{References}

1) Collins, J. F. and Gerby, R. W., J. Metals, 7, 612 (1955).

2) Deeley, G. G., Herbert, J. M. and Moore, N. C., Powd. Metall., No. 8, 145-51 (1961).

3) Terwilliger, G. R., J. Am. Ceram. Soc., 57, C48-49 (1974).

4) Terwilliger, G. R. and Lange, F. F., J. Mater. Sci., 10, 1169-74 (1975).

5) Mitomo, M., J. Mater. Sci., 11, 1103-07 (1976)

6) Lou, V. L. K., Mitchell, T. E. and Heuer, A. H., J. Am. Ceram. Soc., 68, 49-58 (1985).

7) Wada, H., Wang, M.-J. and Tien, T.-Y., J. Am. Ceram. Soc., 71, 837-40 (1988).

8) Heuer, A. H. and Lou, V. L. H., J. Am. Ceram. Soc., 73, 2785-803 (1990).

9) Wada, H., J. Mater. Sci., 26, 2590-94 (1991).

10) Panek, Z., J. Am. Ceram. Soc., 78, 1087-88 (1995).

11) Isomaki, I., NTIS-Report PB96-169735, U. S. Deprt. Comm.
(1995).

12) Rocabois, P., Chatillen, C. and Bernard, C., J. Am. Ceram. Soc., 79, 1351-60, 1361-65 (1996).

13) Greskovich, C. and Prochazka, S., J. Am. Ceram. Soc., 64, C96-97 (1981).

14) Pompe, R., Eklund, L. and Hermansson L., Proc. Brit. Ceram. Soc., No. 31, 97-105 (1981).

15) Lange, F. F., J. Am. Ceram. Soc., 65, C120-21 (1982).

16) Messier, D. R. and Deguire, E. J., J. Am. Ceram. Soc., 67, 602-05 (1984).

17) Baik, S. and Raj, R., J. Am. Ceram. Soc., 68, C124-26 (1985).

18) Heidhardt, U., Schubert, H., Bischoff, E. and Petzow, G., Key Eng. Mater., Vol. 89-91, 187-92 (1994)

19) Hwang, S.-L., Becher, P. E. and Lin, H.-T., J. Am. Ceram. Soc., 80, 329-35 (1997).

20) Lee, W.-H., Kim, H.-E. and Cho, S.-J., J. Am. Ceram. Soc., 80, 2737-40 (1997).

21) Arato, P. and Weber, F., Key Eng. Mater., Vol. 161-163, 221-24 (1999).

22) Yokoyama, K. and Wada, S., J. Ceram. Soc. Japan, 108, 6-9 (2000).

23) Yokoyama, K. and Wada, S., J. Ceram. Soc. Japan, 108, 138-43 (2000)

24) Yokoyama, K. and Wada, S., J. Ceram. Soc. Japan, 108, 230-35 (2000).

25) Yokoyama, K. and Wada, S., J. Ceram. Soc. Japan, 108, 357-43 (2000).

26) Yokoyama, K. and Wada, S., J. Ceram. Soc. Japan, 108, 627-32 (2000).

27) Yokoyama, K. and Wada, S., J. Ceram. Soc. Japan, 109, 238-43 (2001).

28) Hattori, T., Wada, S. and Yokoyama, K., J. Ceram. Soc. Japan, 109 (2001) in press.

29) Hattori, T. and Wada, S., submitted to J. Ceram. Soc. Japan.

30) Tsuge, A., Inoue, H. and Komeya, K., J. Am. Ceram. Soc., 72, 2014-16 (1989)

31) Wada, S., Hattori, T. and Yokoyama, K., J. Ceram. Soc. Japan, 109, 281-83 (2001).

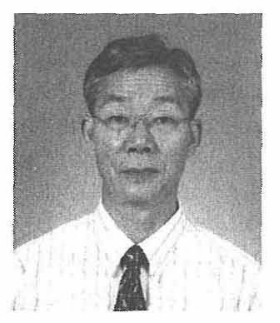

Shigetaka Wada was born in Nagano, Japan, on Dec. 7, 1938. He received B. S. Degree from Department of Physics, Nagoya University in 1961 and D. Eng. Degree from Osaka University in 1990. He worked for NGK Insulators, Ltd. from 1961 to 1982 and for Toyota Central R\&D Labs. Inc. from 1982 to 2001. He was a Guest Professor for Nagasaki University and Toyota Technological Institute from 1994 to 2001. His research interests now are sintering of $\mathrm{Si}_{3} \mathrm{~N}_{4}$ ceramics and thermal conductivity of ceramic materials. 